\title{
WSPOMNIENIE O PROFESORZE JERZYM KACZMARKU (1964-2021)
}

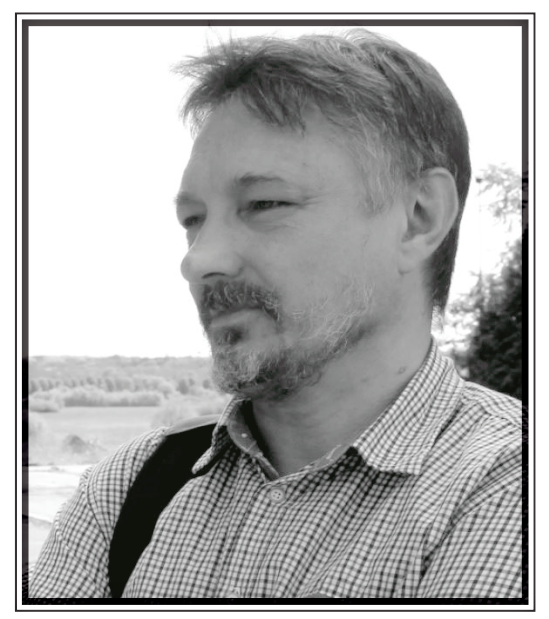

Zdjęcie z zasobów Wydziału Socjologii UAM

Profesor Jerzy Kaczmarek związany przez całe zawodowe życie z poznańskim środowiskiem socjologicznym, urodził się w 1964 roku. Ukończył socjologię na UAM na początku lat 90 . XX wieku. Swoją karierę akademicką rozpoczął w 1994 roku, w 2000 roku obronił rozprawę doktorską zatytułowaną „Utopie społeczne w sztukach plastycznych na przykładzie artystyczno-społecznej koncepcji Josepha Beuysa”. W 2015 roku habilitował się i uzyskał stanowisko profesorskie na UAM.

Specjalizował się w socjologii sztuki, rozwijał refleksję teoretyczną w zakresie socjologii filmu i szerzej: socjologii wizualnej. Założył Pracownię Socjologii Wizualnej przy Instytucie Socjologii UAM, tworząc tym samym podstawy dla 
instytucjonalizacji socjologii wizualnej w Poznaniu i w Polsce. To w dużej mierze prof. Jerzemu Kaczmarkowi zawdzięczamy to, że stała się ona tak ważną częścią poznańskiej i ogólnopolskiej socjologii.

Jerzy Kaczmarek był też specjalistą w zakresie socjologii klasycznej (ze szczególnym uwzględnieniem dorobku niemieckich ojców założycieli nowoczesnej socjologii), rozwijał socjologię pogranicza, angażował się w działania upowszechniające tradycję kulturalizmu Floriana Znanieckiego.

Opublikował wiele prac, m.in. tych wydanych nakładem Wydawnictwa Naukowego UAM: Joseph Beuys. Od sztuki do społecznej utopii (2000), Gubin i Guben - miasta na pograniczu. Socjologiczne studium sąsiedztwa (2011) oraz Zobaczyć społeczeństwo. Film i wideo w badaniach socjologicznych (2014). Redagował między innymi następujące zbiory: Kadrowanie rzeczywistości. Szkice z socjologii wizualnej (2004), Do zobaczenia. Socjologia wizualna w praktyce badawczej (2008). Przez pewien czas kierował Zakładem Socjologii Zróżnicowania Społecznego. Był recenzentem licznych czasopism, w tym „Przeglądu Socjologicznego".

Charakteryzowała go wyrozumiałość, otwartość na pomysły i debatę. Był praktykującym poetą. Wyznaczał własną drogę uprawiania socjologii, choćby wówczas, gdy proponował na konferencjach eseje wizualne czy prezentacje stanowiące połączenie wypowiedzi i obrazu, dalekie od konwencjonalnych wystąpień konferencyjnych.

Był człowiekiem świadomie dystansującym się od pośpiechu współczesności i przygodności ludzkiego losu. Miał wyraziste poglądy, częstokroć idące w poprzek środowiskowego konformizmu. Zawsze był gotowy do współpracy, nie stronił od brania na siebie odpowiedzialności. Łączył wyrazistość i osobność z ludzką życzliwością.

Zmarł 7 kwietnia 2021 roku z powodu choroby nowotworowej

Marek Nowak, Poznań 27 kwietnia 2021 